\title{
Reasoning patterns and modes of prospective biology teachers on embryology learning with TPACK framework
}

\author{
Nia Nurdiani a,1, ${ }^{\star}$, Nuryani Y. Rustaman b,2, Wawan Setiawan b,3, Didik Priyandoko b,4 \\ a Biology Education Study Program, Faculty of Teacher Training and Education, Pasundan University, Jl.Tamansari No. 6-8, Bandung, West Java \\ 40116, Indonesia \\ ${ }^{b}$ Science Education Study Program, School of Postgraduate Studies, Indonesia University of Education, Jl.Dr.Setiabudhi No. 229, Bandung, West \\ Java 40116, Indonesia \\ 1 nurdiani-nia283@unpas.ac.id; 2 nuryani.yogipranata@gmail.com; ${ }^{3}$ wawans@upi.edu; ${ }^{4}$ didikpriyandoko@upi.edu \\ * corresponding author
}

\begin{tabular}{|c|c|}
\hline ARTICLE INFO & ABSTRACT \\
\hline $\begin{array}{l}\text { Article history } \\
\text { Received January 10, } 2019 \\
\text { Revised February 21, } 2019 \\
\text { Accepted March 01, } 2019 \\
\text { Published March 06, } 2019 \\
\text { Keywords } \\
\text { Embriology learning } \\
\text { Prospecive biology teachers } \\
\text { Reasoning patern and mode } \\
\text { Test of logical thinking } \\
\text { TPACK framework }\end{array}$ & $\begin{array}{l}\text { The study was aimed at determining the effectiveness of learning using Technological } \\
\text { Pedagogical and Content Knowledge (TPACK) framework in helping the change of } \\
\text { reasoning patterns and modes of Biology prospective teachers so that it facilitates in } \\
\text { encompassing the Embryology as one of abstract concepts. The subjects used were } 49 \\
\text { students of Biology teachers who were having a contract in Embryology course in Biology } \\
\text { Education Study Program, in a private educational institute in Bandung. The research } \\
\text { design used was quasi-experimental with time-series design type. The measurement of } \\
\text { the level of reasoning ability, patterns, and modes of the students were done through the } \\
\text { Test of Logical Thinking (ToLT) three times (before the learning program takes place, after } \\
\text { learning the first four main subjects, and after the learning program was over). The results } \\
\text { showed that the Embryology learning with TPACK framework could directly change the } \\
\text { from concrete and transitional reasoners categories to formal reasoners. The learning with } \\
\text { TPACK framework also influenced the shift of the students' logical thinking modes; from } \\
\text { the ownership of proportional and/or correlational mode to the ownership of two or three } \\
\text { reasoning modes between proportional, probability, correlational, and combinatorial, } \\
\text { except the variable control mode. } \\
\text { a Copyright } \odot 2019 \text {, Nurdiani et al } \\
\text { a }\end{array}$ \\
\hline
\end{tabular}

\section{INTRODUCTION}

Embryology is one of study areas in Biology that students of Biology prospective teachers must master, in relation to the duty as teachers they will carry out (Aversi-Ferreira et al., 2012; Carlson, 2002; Cassidy, 2016; Garcia, Santos, Moraes, \& Rodrigues, 2016). Within the scope of Embryology, the development process of va-rious types of animals is studied from the fertilized ovum to the time of hatching or birth, which includes variations of the six basic stages, namely: fertilization, cleavage, gastrulation, organogenesis, metamorphosis and gametogenesis (Gilbert, 2010). In general, embryogenesis occurs in the zygote which is not easily observed because of its relatively small size. There are events that take place dynamically, complex, change 
quickly and continuously on macro and microscopic scalea, in three or four dimensions (3- 4D) (Alberts et al., 2002; Hardin, 2008; Reece et al., 2014; Sadler \& Langman, 2012; Yamada et al., 2006). This situation makes concepts in embryology abstract that are difficult to explain and understand (Chen \& Hua, 2017; Kazzazi \& Bartlett, 2017; Lee, 2018; Moraes \& Pereira, 2010).

The mastery of abstract concepts requires high level reasoning ability (Bird, 2010; Effendy, Mudhofir, \& Yulianti, 2018; Susac, Bubic, Vrbanc, \& Planinic, 2014; Yenilmez, Sungur, \& Tekkaya, 2005). Based on Piaget's theory of cognitive development, it can only be owned by someone who reaches adulthood or after his/her cognitive development reaches the reasoning level of formal operation. In fact, the reasoning ability and intelligence of students are not always at an adequate level. The result of preliminary observation using the Test of Logical Thinking (ToLT) instrument (Valanides, 1997) shows that the intellectual development of students in most Embryology lecture participants is still at the reasoning level of concrete operation (Nurdiani, 2012). The cognitive development of formal operation does not only depend on the age of a person, but also cannot be separated from other factors that influence it. Assignment factors in the form of task content, manipulation of instructions in tasks, as well as variables that differ individually, play a role in the development of levels of formal reasoning (Valanides, 1997).

There are five modes of reasoning included in formal level reasoning, namely proportional reasoning, variable control reasoning, probabilistic reasoning, correlational reasoning, and combinatorial reasoning. Proportional reasoning is a reasoning pattern that allows a person to know and interpret the relationships described in the observed variables. Variable control reasoning is the ability to control certain variables from a problem. Probabilistic reasoning is the reasoning that occurs when a person uses information to determine whether a conclusion is possible or not. The correlational pattern is the mindset used by a person to determine reciprocal relationships or inverse relationships between variables. Combinatorial reasoning is the ability of a person to make changes to alternatives that may occur in certain performance (Valanides, 1997).

To overcome the difficulties of students mastering Embryology concepts, a learning program has been developed with the application of the Technological Pedagogical and Content Knowledge (TPACK) framework which combines seven components of knowledge into a single context of the learning program, namely Content Knowledge (CK), Pedagogical Knowledge (PK), Technological Knowledge (TK), knowledge of content and pedagogy (Pedagogical Content Knowledge $=$ PCK), knowledge of technology and content (Technological Content Knowledge $=$ TCK), knowledge of technology and pedagogy (Technological Pedagogical Knowledge $=$ TPK), as well as the complex unity of all components in particular learning contexts (Mishra \& Koehler, 2006; Koehler \& Mishra, 2009).

In the context of Embryology learning, the TPACK framework is built by fulfilling its components with elements chosen wisely, according to TPACK's original characteristics (Mishra \& Koehler, 2006; Koehler \& Mishra, 2009). In addition, the TPACK assessment criteria of a good teacher ar also fulfilled, namely (1) identification of topics taught with technology, such as topics that are difficult for students to understand or topics that are difficult for teachers to teach effectively in the class; (2) identification of representations to change contents taught into forms that students can understand, and are difficult to support in traditional ways; (3) identification of teaching strategies, which are difficult or impossible to be implemented in the traditional way; (4) selection of appropriate computer devices and effective use of pedagogy; and (5) identification of learner centered learning strategies, which are appropriate to be combined with technology (Angeli \& Valanides, 2015).

\section{METHOD}

The implementation of the TPACK framework in the context of Embryology learning in this study was achieved by observing and fulfilling the characteristics of the seven TPACK components, to be mixed in a semester learning program. The components of Content Knowledge (CK) in this study were expressed in the form of Embryology teaching materials that are focused on important main topics identified as difficult for students to understand and difficult for teachers to teach effectively, including the History of Development of Embryological Ideas, Reproductive Organs, Reproductive Neurohormonal Regulation; Gametogenesis (Spermatogenesis and Oogenesis); Fertilization; Cleavage; Gastrulation; and Organogenesis. This shows the fulfillment of the first TPACK assessment criterion of a good teacher TPACK assessment, namely identifying topics taught with technology, such as topics that are difficult for students to understand or topics that teachers are difficult to teach effectively in the class (Angeli \& Valanides, 2015). 
The components of pedagogical knowledge (PK) in this study were reflected in the determination of learning objectives, the preparation of learning plans, and the determination of the TPACK framework and blended learning framework as the preferred learning method used. Blended learning is a learning method that combines independent learning via the internet (e-learning) and in-class learning (Rusman \& Riyana, 2013). The fulfillment of this PK component also meets the second TPACK criterion of a good teacher, namely the identification of teaching strategies, which are difficult or impossible to be implemented in the traditional way (Angeli \& Valanides, 2015).

The component of technology knowledge (TK) in this study was fulfilled by the use of information technology in classroom management, provision of teaching materials, and the Embryology learning process. The PCK com-ponent was reflected in the interpretation of teaching materials into different forms and ways of representation so that it is easier for lecture participants to understand.

This was in line with the fulfillment of the next criterion of the teachers' TPACK implementation, namely the identification of representations to change contents taught into forms that students can understand, and difficult to support in traditional ways (Harr, Eichler, \& Renkl, 2015; Messina \& Tabone, 2012; Muhtadi, Wahyudin, Kartasasmita, \& Prahmana, 2018; Saudelli \& Ciampa, 2014; Wati, Fitriana, \& Mardiyana, 2018).

The TCK component in this study was contained in the use of information technology to change the representation of Embryology teaching materials into interactive multimedia (IM) forms. TPK components were filled with the change of Embryology learning methods into IT assisted learning with the use of Learning Management System (LMS) Moodle as a class management tool in the context of online learning. The fulfillment of the TCK and TPK components was a description of the fulfillment of other criteria for the implementation of the TPACK teacher, namely the selection of the right computer equipment and the use of effective pedagogy; and identification of learner centered learning strategies, which are right to be combined with technology (Angeli \& Valanides, 2015).

In conducting this research, the research design used was a quasi experimental design with time series design type. The study lasted for one semester of learning. The learning in this study was applied to prospective Biology teachers who were currently having a contract in an Embryology lecture in the Biology Education Study Program, at an education institution for education personnel in Bandung, covering a total of 49 students.

The e-learning session of blended learning was carried out by students by accessing teaching materials in the form of IM uploaded into the LMS Moodle application via the internet network on the bio.elearning.unpas.ac.id website. The time given for e-learning was a week long before in-class sessions, with the task of studying and summarizing the main subjects.

An in-class session was carried out in a duration of 150 minutes ( 3 credits). In in-class learning, students of research subjects were given reinforcement of understanding with structured assignments in the form of cases they have to solve through group discussions and presentations. In the sub subjects of the Reproductive System and Gametogenesis, learning was complemented by verificative practicum. In the main subjects of Cleavage, Gastrulation and Organogenesis, the learning was complemented with assignments of embryo modeling using styrofoam.

The measurement of students' level of reasoning ability, pattern and mode is carried out through the Test of Logical Thinking (ToLT). The ToLT instrument consists of 10 written questions covering five types of modes of reasoning (proportional reasoning, variable control, correlational, probability, and combinatorial). Each reasoning mode is represented by two questions. The ToLT score is the basis for categorizing logical thinking bs; scores of $0-1$ for the category of concrete reasoning, scores of $2-3$ for the category of transitional reasoning, and scores of $4-10$ for the category of formal reasoning (Valanides, 1997). ToLT in this study was conducted three times, namely before the learning program took place, after learning the first four subjects, and after the learning program was over. The data were analyzed per individual, then data with the same tendency are group and the percentage was determined. To see the pattern of changes in reasoning levels and modes, the data are represented in the form of a map of changes of reasoning patterns and modes.

\section{RESULTS AND DISCUSSION}

The recapitulation of the number of the students of research subjects with changes in the level of reasoning is presented in the Table 1. The measurement of reasoning levels of the students participating in the Embryology lecture before the learning program takes place is important to be obtained in order to know the categories of reasoning level, so that the appropriate learning strategies/methods can be determined and 
learning objectives can be more easily achieved. The result of ToLT 1 (Table 1) shows that before the intervention/treatment, the subjects of the study were dominated by a group of concrete reasoners of 32 students $(65.31 \%)$; a group of transitional reasoners which includes 15 students $(30.61 \%)$, and a group of formal reasoners consisting only two students $(4.08 \%)$. In this condition, it can be estimated that mastering abstract Embryology concepts is not easily achieved by the subjects without intervention of treatment in the form of learning assisted with a method and media that concretize abstract concepts, while helping to improve reasoning patterns and modes (Aversi-Ferreira et al., 2012; Carlson, 2002; Moraes \& Pereira, 2010; Valanides, 1997).

Table 1. Changes in the number of the students of research subjects in the category of logical thinking ability based on the ToLT scores

\begin{tabular}{lccc}
\hline \multirow{2}{*}{ Reasoning Level Categories } & \multicolumn{3}{c}{ ToLT Scores } \\
\cline { 2 - 4 } & ToLT $_{1}$ & ToLT $_{2}$ & ToLT $_{3}$ \\
\hline Concrete (Score 0 - 1) & $32(65.31 \%)$ & $26(50.06 \%)$ & $10(21.41 \%)$ \\
Transitional (Score 2 - 3) & $15(30.61 \%)$ & $21(42.86 \%)$ & $18(36.73 \%)$ \\
Formal (Score 4 - 10) & $2(4.08 \%)$ & $2(4.08 \%)$ & \\
\hline Total & 49 & 49 & \\
\hline Note : ToLT 1 = the first Test of Logical Thinking & & \\
ToLT 2 = the second Test of Logical Thinking & & \\
ToLT 3 $=$ the third Test of Logical Thinking &
\end{tabular}

The second measurement of the students' reasoning level $\left(\mathrm{ToLT}_{2}\right)$ was conducted after the application of the TPACK framework in learning the first four main subjects, including the History of the Development of Embryolo-gical Ideas, Reproductive Organs, Reproductive Neurohormonal Regulation, and Gametogenesis (Spermatogenesis and Oogenesis). The learning process of the main subject of the Reproductive System is integrated with verificative practicum. The results of $\mathrm{ToLT}_{2}$ (Table 1) show a change in the reasoning patterns of the students. The number of concrete reasoners decreases to 26 people $(50.06 \%)$. The number of transitional reasoners increases to 21 people $(42.86 \%)$, but the number of formal reasoners does not change. This data show that the application of the TPACK framework on the learning of the four Embryology main subjects influences the shift of reasoning patterns from concrete reasoning pattern to transitional reasoning pattern.

The shift in the level of logical thinking ability also appears in the third measurement (ToLT $T_{3}$ (Table 1) which was conducted after the learning of these following four Embryology main subjects (Fertilization, Cleavage, Gastrulation, and Organogenesis). The number of concrete reasoners has decreased to 10 students $(21.41 \%)$, the number of transitional reasoners has decreased to 18 students $(36.73 \%)$, and the number of formal reasoners has increased to 21 students $(42.86 \%)$.

To find out the shift direction of the students' reasoning levels, it can be seen on the map of change of the number of students' with each category of reasoning level shown in Figure 1.

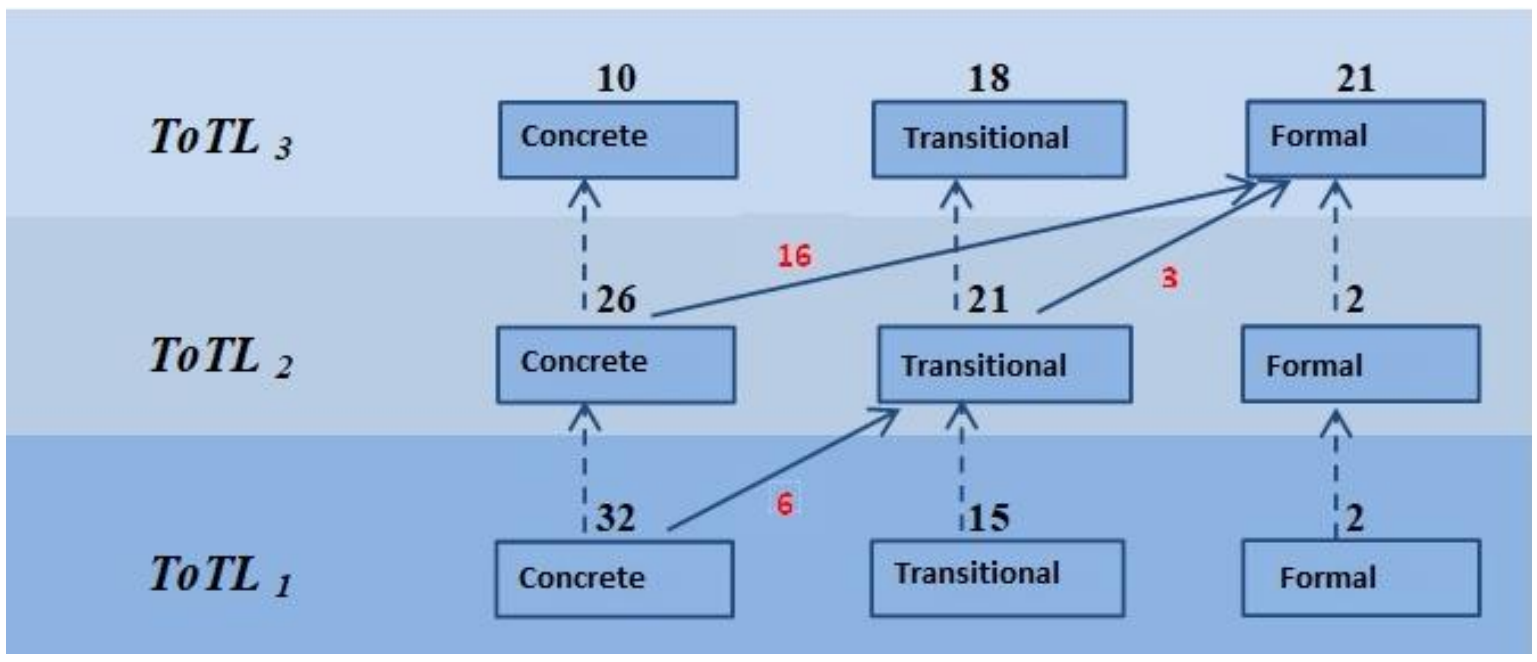

Figure 1. The map of the shift of the students' reasoning patterns after Embryology learning with the application of the TPACK framework. 
The Figure 1 shows that the learning of the four main subjects change the number of concrete reasoniers into transitional reasoners, while the learning of the next four main subjects change concrete and transitional reasoners into formal reasoners. Through this data analysis, it indicates that Embryology learning with the application of the TPACK framework can direct changes in reasoning patterns from the category of concrete reasoning to the formal reasoning. This is in line with the Neimak's statement (Valanides, 1997) which concludes the results of his study that the task contents, the manipulation of instructions in the tasks, and the different variables individually can affect the forma-tion of formal thinking. In the context of this study, the use of interactive multi media enables the visualization of abstract embryological concepts to be more concrete, detailed and systematic. Uploading this interactive multimedia into the Moodle LMS that can be accessed online, allows students to increase their access to information, and improve self-regulation in learning. Thus, for the students this learning becomes more meaningful, interesting and facilitates understanding and formation of formal thinking.

Embryology learning with the TPACK framework also affects the reasoning mode shifts. The results of the analysis of the correct answers on the ToLT items are presented in Table 2.

Table 2. Changes in the number of the students in the logical thinking mode based on the correct answers to the ToLT items

\begin{tabular}{lccc}
\hline \multirow{2}{*}{ Reasoning modes } & \multicolumn{3}{c}{ Number of Students with Correct Answers } \\
\cline { 2 - 4 } & ToLT 1 & ToLT $_{2}$ & ToLT $_{3}$ \\
\hline Proportional (Items 1/2) & 19 & 27 & 31 \\
Variable Control (Items 3/4) & 3 & 6 & 7 \\
Probability (Items 5/6) & 7 & 2 & 20 \\
Correlational (Items 7/8) & 10 & 19 & 20 \\
Combinatorial (Items 9/10) & 0 & 3 & 45 \\
\hline
\end{tabular}

Note : $T_{0 L T}=$ the first Test of Logical Thinking

$\mathrm{TOLT}_{2}=$ the second Test of Logical Thinking

$\mathrm{TOLT}_{3}=$ the third Test of Logical Thinking

The results of ToLT 1 show that the research subjects are dominated by students who hava proportional and correlational reasoning modes. As ToL $T_{1}$ was conducted before the Embryology learning program with TPACK, the ownership of both reasoning modes is a representation of previous learning experiences. ToLT 2 which was conducted after the learning of the four main subjects shows the results of the ownership of more dispersed reasoning mode covering all types of reasoning modes. The detailed data of measurement results shows that almost every student has a combination of two or three reasoning modes, that is between proportional, probability and correlational, except for the variable control mode which is only possessed by very few students (6 students). It seems that changing the representation of embryological teaching material presented in the multimedia in this study, besides allowing students to know and interpret the relationships depicted in the observed variables (proportional reasoning mode), is also sufficient to encourage student reasoning to use the information obtained in determining the possibility of drawing a conclusion (probabilistic reasoning mode), and determining reciprocal relationships or inverse relationships between variables (correlational reasoning mode). The non-establishment of variable control reasoning mode can be expected to occur because the method used in the Embryology learning process with TPACK framework, especially practicum which is only verification without being experimental/manipulative and problem statements that are less challenging in discussions, is not enough to train students to develop their ability to control certain variables from a problem.

$\mathrm{ToLT}_{3}$ which was conducted after the learning of the next four main subjects gain results that were not much different from the results of ToLT $T_{2}$, except for the increase in the number of students who have a combinatorial reasoning mode ( 45 students). In the learning of the last four main subjects, the students were given assignments in the form of making models of embryos made from styrofoam in the shapes of balls and slabs. This assignment seems to play a strong role in the development of the ownership of the students' combinatorial mode. Combinatorial reasoning is an ability of a person to determine an alternative that might occur in certain situations systematically (Kaygısız \& Gürkan, 2018; Ong, Zaki, \& Goodman, 2015; Valanides, 1997; Whitebread et al., 2017).

The TPACK framework is a complex interaction of the seven components of knowledge (CK, PK, TK, PCK, TCK, TPK, and TPACK). Therefore, increasing the pattern and mode of reasoning in this study is the combined effect of each of the strengths and weaknesses of each component. Thus, the success of learning 
with the TPACK framework approach is very dependent on the accuracy of determining the type of element of each component that is integrated.

In embryology learning there are many difficult terms that must be memorized and understood so students often misunderstand the concepts given. Using TPACK allows students to like and enjoy learning. If the learning can be enjoyed and implemented properly by students, it will be able to make students concentrate in accepting and understanding the concepts learned.

Learning in ancient times was only required by teachers to master aspects of subject matter and pedagogics only. Now with the development of technology, the teacher must be able to keep up with technology. Based on this, integration between material, technology and pedagogy is needed. Integrating technology in learning is not an easy thing, because to be able to choose the right technology the teacher must master the material to be taught so that it can analyze the characteristics of the material. The teacher must also consider the strategies in learning according to the technology used. TPACK requires a relationship of interaction that is synergy between material, pedagogy and technology.

TPACK with learning devices also has a relationship, where teachers who have high TPACK can develop high learning tools as well. This is because TPACK is essential knowledge that can influence the learning method. Preparation of learning planning using technology and in accordance with TPACK criteria does not mean only inserting the use of technology in learning. The main thing in preparing learning devices using TPACK is the learning objectives and activities then the appropriate technology is chosen.

TPACK has advantages such as in the preparation of instructional design, learning instruction, learning models and strategies, assessment systems and curriculum design. Based on these advantages, TPACK contributes greatly to changes and learning paradigms.

The use of informatics technology to transform the representation of embryological teaching materials into interactive multimedia forms uploaded into the LMS Moodle, the use of blended learning methods, and other structured assignments, which are carried out in an integrated manner have helped students improve their pattern and mode of reasoning, which in turn will help overcome difficulties in mastering the concept of embryology.

\section{CONCLUSION}

Based on the results of this study, it can be concluded that the implementation of the TPACK framework in the context of Embryology learning for the students of Biology prospective teachers plays a very important role in building patterns and modes of logical thinking. The Embryology learning with TPACK framework can direct changes in reasoning patterns from categories of concrete and transitional reasoners to the category of formal reasoners. This learning also influences the shift of the students' logical thinking mode; from the ownership of proportional and or correlational modes to the ownership of two or three reasoning modes between proportional, probability, correlational and combinatorial, except for variable control modes.

\section{ACKNOWLEDGMENT}

Acknowledgments and high appreciation were conveyed to the head of the Faculty of Teacher Training and Education, Universitas Pasundan, which has given permission and facilitated this study, as well as to the head of the Graduate School, Universitas Pendidikan Indonesia, which has provided learning opportunities.

\section{REFERENCES}

Alberts, B., Johnson, A., Lewis, J., Raff, M., Roberts, K., \& Walter, P. (2002). Molecular biology of the cell (4th Ed.). New York, US: Garland Science. doi: https://doi.org/10.2460/ajvr.75.7.613

Angeli, C., \& Valanides, N. (2015). Technological pedagogical content knowledge. doi: https://doi.org/10. 1007/978-1-4899-8080-9

Aversi-Ferreira, T. A., Aversi-Ferreira, R. A. G. M. F., Do Nascimento, G. N. L., Nyamdavaa, E., Araujo, M. F., Ribeiro, P. P., Nishijo, H. (2012). Teaching embryology using models construction in practical classes. International Journal of Morphology, 30(1), 188-195. doi: https://doi.org/10.4067/S0717-950220120001 00034

Bird, L. (2010). Logical reasoning ability and student performance in general chemistry. Journal of Chemical Education, 87(5), 541-546. doi: https://doi.org/10.1021/ed8001754

Carlson, B. M. (2002). Embryology in the medical curriculum. Anatomical Record, 269(2), 89-98. doi: https:// 
doi.org/10.1002/ar.10075

Cassidy, K. M. (2016). Embryology in medical education: a mixed methods study and phenomenology of faculty and first year medical students, (June). Indiana University. doi: https://doi.org/10.7912/C2VS38

Chen, X., \& Hua, X. (2017). Application of three dimensional teaching method in histology and embryology course. In Advances in Social Science, Education and Humanities Research (Vol. 101, pp. 1327-1331). doi: https://doi.org/10.2991/icemct-17.2017.286

Effendy, S., Mudhofir, F., \& Yulianti, I. (2018). Analysis of the implementation of reasoning learning based on the scientific approach in physics learning. Journal of Innovative Science Education, 7(2), 293-298. doi: https://doi.org/10.15294/jise.v7i2.26570

Garcia, L. G., Santos, D. C. dos, Moraes, M. G. de, \& Rodrigues, G. M. (2016). EMBRIO v2.0 - A virtual learning environment for embryology teaching. International Journal of Information and Education Technology, 7(4), 297-300. doi: https://doi.org/10.18178/ijiet.2017.7.4.884

Gilbert, S. F. (2010). Developmental Biology (Ninth edit). Sunderland (MA): Sinauer Associates, Inc. Retrieved from https://www.ncbi.nlm.nih.gov/books/NBK9983/

Hardin, J. (2008). The missing dimension in developmental biology education. CBE-Life Sciences Education, 7(1), 13-16. doi: https://doi.org/10.1187//se.7.1.cbe13

Harr, N., Eichler, A., \& Renkl, A. (2015). Integrated learning: Ways of fostering the applicability of teachers' pedagogical and psychological knowledge. Frontiers in Psychology, 6(JUN), 1-16. doi: https://doi.org/ 10.3389/fpsyg.2015.00738

Kaygısız, G. M., \& Gürkan, B. (2018). Adaptation of Scientific Reasoning Scale into Turkish and Examination of its Psychometric Properties. Educational Sciences: Theory \& Practice, 18(3), 737-757. doi: https:/l doi.org/10.12738/estp.2018.3.0175

Kazzazi, F., \& Bartlett, J. (2017). Condensing embryology teaching for medical students: can it be taught in 2 hours? Advances in Medical Education and Practice, 8, 797-806. doi: https://doi.org/10.2147/amep. s151880

Koehler, M. J., \& Mishra, P. (2009). What is technological pedagogical content knowledge (TPACK)? Contemporary Issues in Technology and Teacher Education, 9(1), 60-70. doi: https://doi.org/10.1016/j. compedu.2010.07.009

Lee, Y. (2018). Proper level of knowledge on anatomy for learning embryology - based in the survey analysis on the newly introduced teaching method (Group presentation of anatomy) to the embryology class. Korean Journal of Physical Anthropology, 31(3), 91-98. doi: https://doi.org/10.11637/kjpa.2018.31.3.91

Messina, L., \& Tabone, S. (2012). Integrating technology into instructional practices focusing on teacher knowledge. In Procedia - Social and Behavioral Sciences (Vol. 46, pp. 1015-1027). doi: https://doi. org/10.1016/j.sbspro.2012.05.241

Mishra, P., \& Koehler, M. J. (2006). Technological pedagogical content knowledge: A framework for teacher knowledge. Teachers College Record, 108(6), 1017-1054. doi: https://doi.org/10.1111/j.14679620.2006.00684.x

Moraes, S. G., \& Pereira, L. A. V. (2010). A multimedia approach for teaching human embryology: Development and evaluation of a methodology. Annals of Anatomy, 192(6), 388-395. doi: https://doi. org/10.1016/j.aanat.2010.05.005

Muhtadi, D., Wahyudin, Kartasasmita, B. G., \& Prahmana, R. C. I. (2018). The Integration of technology in teaching mathematics. In Journal of Physics: Conference Series (Vol. 943). doi: https://doi.org/10. 1088/1742-6596/943/1/012020

Nurdiani, N. (2012). Kemampuan awal berpikir logis mahasiswa calon guru biologi peserta kuliah embriologi. Bandung. Retrieved from nurdiani-nia283@unpas.ac.id.

Ong, D. C., Zaki, J., \& Goodman, N. D. (2015). Affective cognition: Exploring lay theories of emotion. Cognition, 143, 141-162. doi: https://doi.org/10.1016/j.cognition.2015.06.010

Reece, J. B., Urry, L. A., Cain, M. L., Wasserman, S. A., Minorsky, P. V., \& Jackson, R. B. (2014). Campbell Biology (11th Ed.). London: Pearson. Retrieved from https://www.pearson.com/us/higher-education/ product/Reece-Campbell-Biology-10th-Edition/9780321775658.html

Rusman, D. K., \& Riyana, C. (2013). Pembelajaran berbasis teknologi informasi dan komunikasi: Mengembangkan profesionalitas guru (1st Ed.). Jakarta: Rajawali Pers. Retrieved from http://library. um.ac.id/free-contents/downloadpdf.php/buku/pembelajaran-berbasis-teknologi-informasi-dan-komunika si-mengembangkan-profesionalitas-guru-rusman-deni-kurniawan-cepi-riyana-43912.pdf

Sadler, T. W., \& Langman, J. (2012). Langman's medical embryology (12th ed.). Philadelphia: Wolters Kluwer 
Health/Lippincott Williams \& Wilkins. Retrieved from https://www.ncbi.nlm.nih.gov/nlmcatalog/10156 2744

Saudelli, M. G., \& Ciampa, K. (2014). Exploring the role of TPACK and teacher self-efficacy: An ethnographic case study of three iPad language arts classes. Technology, Pedagogy and Education, 25(2), 227-247. doi: https://doi.org/10.1080/1475939X.2014.979865

Susac, A., Bubic, A., Vrbanc, A., \& Planinic, M. (2014). Development of abstract mathematical reasoning: the case of algebra. Frontiers in Human Neuroscience, 8(September), 1-10. doi: https://doi.org/10.3389/fn hum.2014.00679

Valanides, N. (1997). Formal reasoning abilities and school achievement. Studies in Educational Evaluation. doi: https://doi.org/10.1016/S0191-491X(97)00011-4

Wati, S., Fitriana, L., \& Mardiyana, M. (2018). Technological pedagogical content knowledge of junior high school mathematics teachers in teaching linear equation. In Journal of Physics: Conference Series (Vol. 1008). doi: https://doi.org/10.1088/1742-6596/1008/1/012067

Whitebread, D., Neale, D., Jensen, H., Liu, C., Solis, S. L., Hopkins, E., Zosh, J. (2017). The role of play in children's development: a review of the evidence (White pape). DK: The LEGO Foundation. Retrieved from https://www.legofoundation.com/media/1065/play-types-_-development-review_web.pdf

Yamada, S., Uwabe, C., Nakatsu-Komatsu, T., Minekura, Y., Iwakura, M., Motoki, T., Shiota, K. (2006). Graphic and movie illustrations of human prenatal development and their application to embryological education based on the human embryo specimens in the kyoto collection. Developmental Dynamics, 235(2), 468-477. doi: https://doi.org/10.1002/dvdy.20647

Yenilmez, A., Sungur, S., \& Tekkaya, C. (2005). Investigating students' logical thinking abilities: the effects of gender and grade level. Hacettepe Üniversitesi Eğitim Fakültesi Dergisi, 28, 219-225. Retrieved from http://dergipark.gov.tr/download/article-file/87731 